\title{
Design of WSN based Water Quality Monitoring System in a Mining District
}

\author{
B. Kameswara Rao ${ }^{1}$, A. S. N. Chakravarthy ${ }^{2}$, M. Jagannadha Rao ${ }^{3}$, G. Raja Rao ${ }^{4}$ \\ ${ }^{1}$ Department of CSE, JNTUK, Kakinada, India \\ ${ }^{2}$ Department of CSE, JNTUKUCE, Vizianagaram, India \\ ${ }^{3,4}$ Department of Geology, Andhra University, Visakhapatnam, India
}

\begin{abstract}
Mineral resources are non-renewable asserts and India is blessed with abundant mineral resources including metallic minerals, nonmetallic minerals, fuels etc. The liberalized policy of government of India attracted number of mining companies from India and abroad and started mining of these resources at various places of the Nation. This resulted a severe environmental impact on various sub environments including surface water and groundwater. In this paper it is proposed the conceptual model of design and implementation of wireless sensor network (WSN) using ZigBee Protocol for continuous monitoring of pollution levels in water resources due to mining activity of a given region using a multiple sensor system. The details of the model, the hardware system the networking application, advantages are presented. It is established that, the wireless sensor network system can be effectively implemented to monitor quality of water resources in a mining district.
\end{abstract}

Keywords: WSN, Mining, Pollution, ZigBee Protocol, Water Resources

\section{Introduction}

Mining is an important industry for any nation. Mineral resources are non-renewable natural assets, which provide raw materials for various industries, which will produce finished products for the development of the country's economy. These resources include metallic minerals, nonmetallic minerals Fuels, precious metals and gemstones. In recent times the liberalized economic policy of this country resulted active involvement private mining companies, and exploration and exploitation of mineral resources of this country has reached a rapid pace. Mining will have direct impact on environment, because of the fact, it will disturb the natural strata to reach the valuable mineral beneath. There are many types of environmental impacts including subsidence, dust generation, air pollution, waste generation, removal of forests, effects on fauna and flora, displacement of natural habitat, disturbing drainage, pollution of surface water and groundwater etc. A number of studies at global level established thepotential impact of mining on water resources (Tarras-Wahlberga et.al , 2001, Pyatt et.al,2000, Mummey Daniel et.al,2002, Steinhause et.al,2009 , Niyogi et.al,2002, Renberg et.al,2001, Ryan, Paddy et.al,1991). There are stringent laws and guidelines imposed by the government to reduce the impact on environment due to mining, however in practice the implementation of these guidelines is far from satisfactory. Innovation and application of information technology in environmental protection is order of the day. Recent development in software technology including technologies related to wireless protocol have been thought of for monitoring the environmental pollution. In this paper the wireless sensor network system (WSN) has been proposed to continuously monitor the pollution of surface water bodies and groundwater resources of a given mining district. This conceptual model is proposed herewith.

According to Lambebo and Haghani (2014) a wireless sensor network (WSN) generally consists of a large number of low- cost and low-power multifunctional sensor nodes which can sense the water quality parameters, that are deployed in a region of interest, in this case a mining district. In WSN, the nodes communicate wirelessly over short distances and are capable of organizing themselves in an autonomous multihop mesh network (J. Yang and X. Li, 2010). A WSN can be generally described as a network of nodes that cooperatively sense and may control the environment enabling interaction between persons or computers and the surrounding environment A typical sensor node in a WSN consists of a wireless communication unit, a microprocessor, a data acquisition unit, memory unit, and sensor boards. The microprocessor and the memory unit control how often the sensor measurements are taken or transmitted. The measurements can be taken in fixed time intervals or based on an event driven model (Giannopoulos et.al, 2009). The data collected by the sensors is then sent to a base station where the data can be stored for analysis and processing. The application of WSN for environmental monitoring has been studied in the literature. For example, in (ZigBee specifications, 2005), WSNs were used to gather forest temperature data and the amount of rainfall. In (Mittal. Ruchi and Bhatia, 2010), MasliNET, a multimodel environmental monitoring system built for microclimate and pest monitoring in olive groves, was introduce. In general the network consists of two nodes and a base station. A ZigBee wireless communication module (Jelicic.Vana,Razav et.al,2011), is used as the wireless communication unit in the sensor nodes. ZigBee is selected (Table-1) as it is a low-cost and low-power wireless communication protocol and it has been shown to be a viable technology for sensor applications (Cuomo et.al, 2007). These wireless modules are easy to configure and suitable for point-to-point, multipoint and convertible to a mesh network (Cuomo et.al, 2007). The captured data is made available to the user through a graphic application programming interface (API). The designed network is suitable for the monitoring of temperature and greenhouse gases in warehouses and factory settings. 


\section{International Journal of Science and Research (IJSR) \\ ISSN (Online): 2319-7064 \\ Index Copernicus Value (2013): 6.14 | Impact Factor (2015): 6.391}

According to Lambebo and Haghani (2014) The Wireless Sensor Network (WSN) can be implemented using a tree topology in beacon mode (data being sent continuously without interruption) where sensors collect data and send it to the base station which is the task manager of the network. The proposed WSN architecture is shown in Fig. 1. Two individual environmental sensor nodes serving as transmitters can be designed to collect, process, and transmit the data in real time. The system operates within a range of $100 \mathrm{~m}$ from the base station and is suitable for monitoring the concentration of pollutants in both surface water and groundwater. The base station, which is the network coordinator, manages the activities of individual nodes by periodically requesting data. In addition to data integration and analysis, the base station also relays processed data to display devices and PDAs. The base station is equipped with an Arduino Uno Microcontroller for system coordination, a receiving ZigBee module and a Wi-Fi__33 module for wireless communication and data transmission over the $802.11 \mathrm{~b} / \mathrm{g}$ wireless networks, which make it possible to access the collected data via the Internet. In addition, the captured data is inserted into a MySQL database where a webpage with a graphing application programming interface (API) is used to display the data.

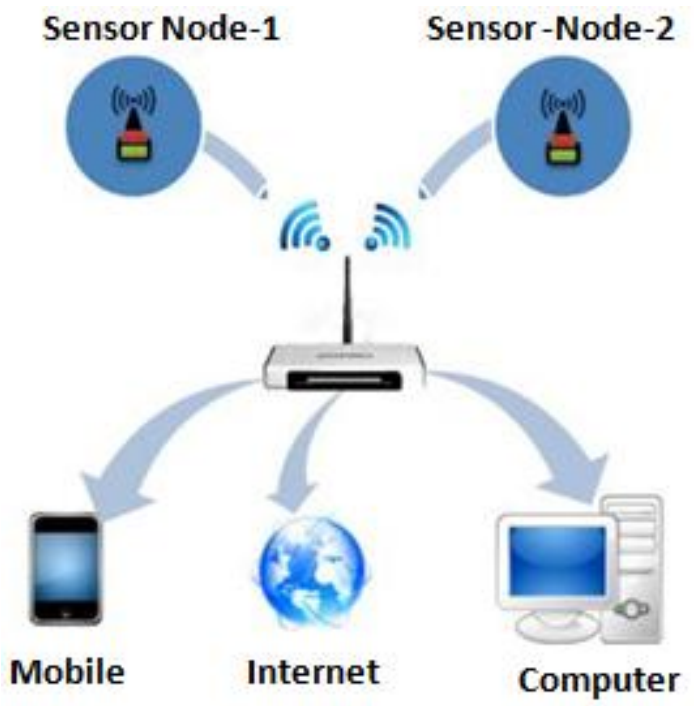

\section{Network Architecture}

A. Transmitter Node to achieve a power efficient network, open source and low-power consumption hardware were used to implement the transmitter. The structure of the transmitting nodes and the final product are shown in Fig. 2. Each transmitting node consists of one off-the shelf XBee wireless module, water quality Sensors, and a GPS module. The XBee wireless module operates on the 802.15.4 protocol at a frequency of $2.4 \mathrm{GHz}$ with a power output of $1 \mathrm{~mW}$ and a data transmission rate of $250 \mathrm{kbps}$, which ensures the wireless nature of the network. The sensor system consist of all sensors capable of sensing the required parameters of both surface water and groundwater (Tables 1 and 2) with a power consumption of $<350 \mathrm{mw}$ at $5 \mathrm{~V}$. A GTPA013 ultimate GPS module with a $-165 \mathrm{dBm}$ sensitivity and only $20 \mathrm{~mA}$ current draw is added to the transmitter node. This determines the location of the sensor node at all time. Each transmitting node is powered up using a $9 \mathrm{~V}$ battery and the data collected is wirelessly sent to the base station for processing, display, and storage. To program the Arduino controller in the transmitter node, the Arduino open source environment can be used where the $\mathrm{C}++$ programming language was utilized. For each sensor, using the data sheets provided by the manufacturer, a distinct code and library will be implemented.

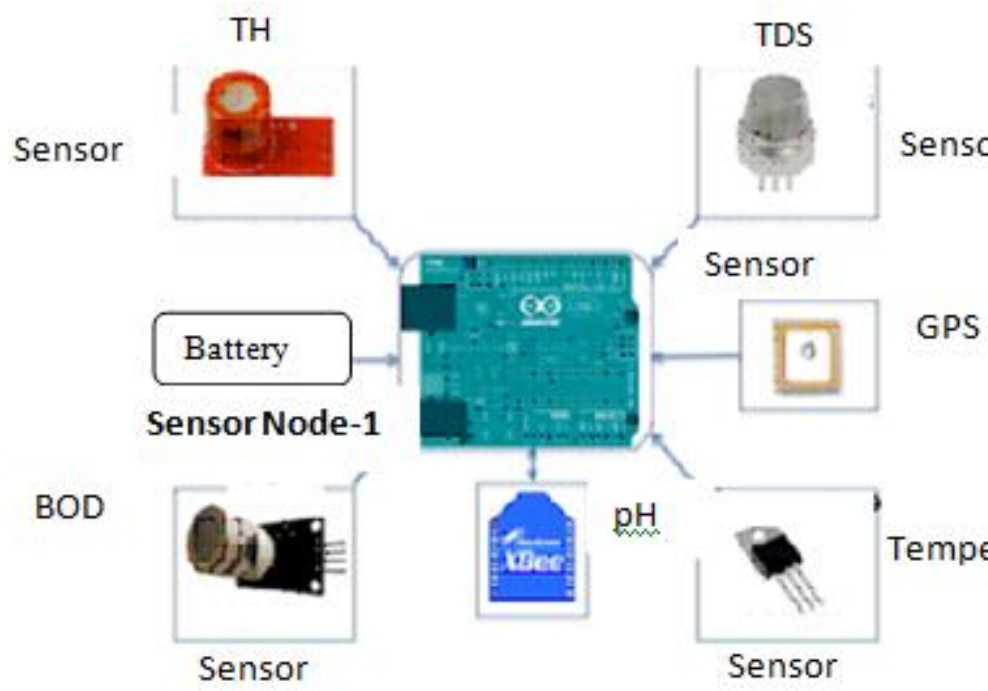

Figure 2: Ideal Transmitting Node structure

Base Station: The base station will be constructed using open source and low-power consumption hardware. An XBee wireless module, operating on the IEEE 802.15.4 protocol at a frequency of $2.4 \mathrm{GHz}$ and a power output of $1 \mathrm{~mW}$ was used as the wireless module. To allow wireless relay of data over the Internet one WRL-09954 WiFly shield will be used that allows connection to $802.11 \mathrm{~b} / \mathrm{g}$ wireless networks (Wi-Fi) network.

The tasks of the base station are given below:

- To coordinate the two transmitting nodes by sending periodic data requests. .

- To receive environmental data from all transmitting nodes in real time.

- To relay the received data to display devices for a remote visualization.

\section{Data Collection and Analysis:}

- Collect continuous and real time sensor data from each sensor.

- Process the inputs from each sensor using the corresponding sensor code.

- Transmit the processed data to the base station periodically for further analysis and display.

It is now established that much of the groundwater pollution is caused by human activities, especially mining. Mining wastes pollute streams and rivers. Ore fines and toxic substances carried by rain water into nearby water courses, alters their chemistry and often makes the water unfit for human use. By locating mineral treatment facilities near the mines, water pollution problems get worse. These units use 


\section{International Journal of Science and Research (IJSR) \\ ISSN (Online): 2319-7064 \\ Index Copernicus Value (2013): 6.14 | Impact Factor (2015): 6.391}

enormous quantities of water for washing the ores. The untreated effluents, slimes or tailings are often released into neighboring streams or lakes. In many cases, the latter are the sources of water supply to the population.

The large scale mining operations going on in the region have adversely affected groundwater table in many areas with the result that yield of water from the wells of adjoining villages has drastically reduced. Further, effluents discharged from mine sites have seriously polluted the streams and under groundwater of the area. Acid mine drainage, liquid effluents from coal handling plants, colliery workshops and mine sites and suspended solids from coal washeries have caused serious water pollution in the region, adversely affecting fish and aquatic life. The Fig-3 and Fig -4 are indicating pollution of water resources
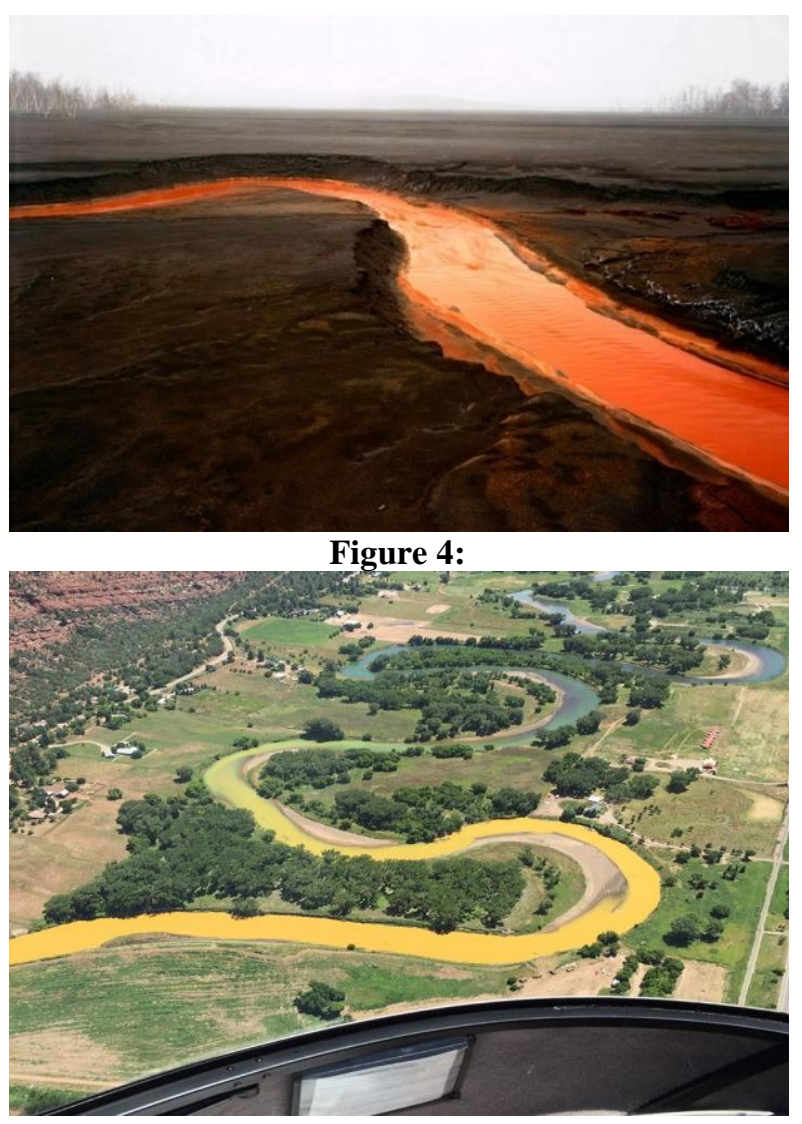

Figure 5:
The possible impact on parameters groundwater and Surface water is shown in Table-2 and Table-3 Fig4 and Fig -5

\section{Network Protocol}

\section{Why ZigBee:}

After the comparison of network protocols merits and demerits in wastewater environment, it is better that we apply ZigBee protocol in mining region and GSM/GPRS protocol in communication between water source and control center.

There are three reasons why we choose ZigBee in mining area. Firstly, because the sampling frequency is one sample per or longer time, and the amount of each sensor's data is few, we do not need high data rate. When more serious water pollution happens, the alarm system will inform concerned immediately according to the warning indicators. Secondly, the wireless range should cover the whole mining area and control center. Thirdly, we want to set energy harvesting module in our water quality monitoring system, so the lower power consumption is necessary. All these conditions are available in ZigBee protocol.

The Comparison of Zigbee, Bluetooth, WiFi, UWB is shown the Table-1

The advantages of this model:-The application of (WNS) in a monitoring of groundwater and surface water pollution levels in a mining district will have the following advantages.

Table 1 (After Lambebo and Haghani (2014)

\begin{tabular}{|c|c|c|c|c|}
\hline & Zigbee & Bluetooth & WiFi & UWB \\
\hline Frequency & $2.4 \mathrm{GHz}$ & $2.4 \mathrm{GHz}$ & $2.4 \mathrm{GHz}$ & $3.1 \mathrm{GHz}-10.6 \mathrm{GHz}$ \\
\hline Range & $30 \mathrm{~m}-1.6 \mathrm{~km}$ & $6 m-62 m$ & $20 \mathrm{~m}-200 \mathrm{~m}$ & $0.2 \mathrm{~m}-40 \mathrm{~m}$ \\
\hline Data rate & $250 \mathrm{kbps}$ & $1 \mathrm{Mbps}$ & 11-54 Mbps & 53-480Mbps \\
\hline Power consumption & Low & Medium & High & Low \\
\hline Cost & Low & Low & High & High \\
\hline Modulation/protocol & DSSS, CSMA/CA & FHSS & DSSS/CCK, OFDM & M-CSMA/OFDM \\
\hline Security & Medium & High & Low & High \\
\hline Network type & Star, tree, mesh & Star(8 nodes max $)$ & Star & \\
\hline Max packet size (bytes) & 132 & 359 & 4096 & \\
\hline Stack size & $8-60 \mathrm{~KB}$ & $>100 \mathrm{~KB}$ & $>100 \mathrm{~KB}$ & \\
\hline Wireless standard & IEEE 802.15 .4 & \begin{tabular}{|l|} 
IEEE 802.15.1X \\
\end{tabular} & IEEE 802.11b IEEE & IEEE 802.15 .3 \\
\hline Main application & $\begin{array}{c}\text { Industrial \& medical sensor } \\
\text { network, etc }\end{array}$ & Phones, PDA, headsets & $\begin{array}{l}\text { Internet access, LAN } \\
\text { connection }\end{array}$ & $\begin{array}{c}\text { Home entertainment, } \\
\text { soundsystem, wireless hard drive }\end{array}$ \\
\hline
\end{tabular}

Volume 5 Issue 6, June 2016 www.ijsr.net 


\section{International Journal of Science and Research (IJSR) \\ ISSN (Online): 2319-7064 \\ Index Copernicus Value (2013): 6.14 | Impact Factor (2015): 6.391}

1) The data generated will be continuous, authentic and cannot be tampered.

2) The cost involved in the traditional methods of field work, sample collection, sample analysis can be reduced significantly.

3) The data generated continuously can be reported, graphically represented and indicated as temporal and spatial variability in the pollution in the mining district.

The data can be uploaded on to a website for public awareness and also for the government to take necessary action, in case of violation. Such networks can be build by connecting all mining regions and for centralized monitoring.

\section{Conclusion}

The application of WSN in environmental protection has been under used in different fields in this paper the application of WSN has been proposed using ZigBee protocol. The conceptual model proposed in this paper can be successfully implemented for the environmental monitory of surface water and ground water in a mining district.

Table 2

\begin{tabular}{|c|c|c|}
\hline $\begin{array}{c}\text { S. } \\
\text { No }\end{array}$ & parameter & $\begin{array}{c}\text { Highest perimetted } \\
\text { value for water }(\mathrm{Si})\end{array}$ \\
\hline 1 & $\mathrm{pH}$ & 7.5 \\
\hline 2 & TDS(mg/l) & 500 \\
\hline 3 & Total Hardness(mg/l) & 300 \\
\hline 4 & Chloride $(\mathrm{mg} / \mathrm{l})$ & 250 \\
\hline 5 & Nitrate $(\mathrm{mg} / \mathrm{l})$ & 45 \\
\hline 6 & Turbidity(NTU) & 10 \\
\hline 7 & Fluoride $(\mathrm{mg} / \mathrm{l})$ & 1.5 \\
\hline 8 & Fe(mg/l) & 0.3 \\
\hline 9 & Calcium Hardness(mg/l) & 75 \\
\hline 10 & Magnesium $(\mathrm{Mg} / \mathrm{l})$ & 30 \\
\hline
\end{tabular}

Table3

\begin{tabular}{|c|c|c|}
\hline Parameter & Description & Significance \\
\hline $\begin{array}{l}\text { Aesthetic } \\
\text { objective }\end{array}$ & $\begin{array}{l}\text { What the water looks like (colour and } \\
\text { cleanliness) }\end{array}$ & $\begin{array}{l}\text { The appearance of water can affect its acceptance by consumers even } \\
\text { if it is considered safe to drink (Alberta, Water Quality Testing,2012) }\end{array}$ \\
\hline Cyanide & A compound of nitrogen and carbon & $\begin{array}{l}\text { Cyanide is highly lethal to humans in large doses, but can be } \\
\text { efficiently detoxified by the body in smaller doses. ( Cyanide, } \\
\text { Environmental and Workplace Health, 2008) Cyanide is also toxic to } \\
\text { fish and other aquatic organisms at high concentrations. (AQUAMIN, } \\
\text { Assessment of the Aquatic Effects of Mining in Canada,1996) }\end{array}$ \\
\hline Hardness & $\begin{array}{l}\text { The amount of dissolved calcium and } \\
\text { magnesium present measured in terms of } \\
\text { calcium carbonate }(\mathrm{CaCO} 3)\end{array}$ & $\begin{array}{l}\text { Hard water is non-toxic, but can require treatment before it can be } \\
\text { used for washing or high-temperature applications. The minerals in } \\
\text { hard water prevent soap from lathering, and can leave a scaly residue } \\
\text { on boilers and kettles when the hot water evaporates. (Boyd and } \\
\text { Boston, Water quality: An introduction, } 2000 \text { ) }\end{array}$ \\
\hline $\begin{array}{l}\text { Fecal } \\
\text { coliforms }\end{array}$ & $\begin{array}{l}\text { Bacteria such as E.Coli which are found } \\
\text { in the feces of humans and other animals }\end{array}$ & $\begin{array}{l}\text { The detection of fecal coliforms is an indicator of the possible } \\
\text { presence of pathogens or parasites which would make the water unsafe } \\
\text { for humans to drink. (Alberta, Water Quality Testing, 2012, City of } \\
\text { Vancouver. Drinking Water Quality, 2011) E.Coli contamination of a } \\
\text { drinking water well was responsible for the Walkerton, Ontario } \\
\text { tragedy in 2000. (CBC News Online. Inside Walkerton, In Depth, } \\
2004 \text { ) }\end{array}$ \\
\hline $\begin{array}{l}\text { Total } \\
\text { dissolved } \\
\text { solids (salts) }\end{array}$ & $\begin{array}{l}\text { Measure of dissolved minerals including } \\
\text { sodium, calcium,magnesium, potassium, } \\
\text { chloride, fluoride, sulphide, carbonate, } \\
\text { andbicarbonate, and others }\end{array}$ & $\begin{array}{l}\text { Salty water can be unsuitable for irrigation, as it can leave salt on } \\
\text { agricultural fields when it evaporates. (Alberta, Water Quality } \\
\text { Testing,2012) Fluoride prevents tooth decay at low concentrations, but } \\
\text { can cause tooth discoloration at higher levels. (Alberta, Water Quality } \\
\text { Testing,2012) }\end{array}$ \\
\hline Trace metals & $\begin{array}{l}\text { Includes arsenic, aluminum, barium, } \\
\text { cadmium, copper, lead, nickel, zinc, } \\
\text { aluminum, cadmium, iron, manganese, } \\
\text { molybdenum, mercury, selenium, silver, } \\
\text { uranium, and others }\end{array}$ & $\begin{array}{l}\text { Some metals are essential nutrients in small quantities and are } \\
\text { important for the growth and development of organisms. (Boyd and } \\
\text { Boston, Water quality: An introduction, 2000) However, at higher } \\
\text { concentrations metals can have harmful effects on humans and aquatic } \\
\text { life. (Guidelines for Canadian Drinking Water ,2010) Individual } \\
\text { metals are measured separately, and have different levels at which they } \\
\text { are considered to be safe. (Metro Vancouver. Physical and chemical } \\
\text { analysis of water supply ,2011) }\end{array}$ \\
\hline Nutrients & $\begin{array}{l}\text { Includes nitrogen and phosphorous } \\
\text { chemical compounds }\end{array}$ & $\begin{array}{l}\text { Nitrogen and phosphorous are important components of living } \\
\text { organisms, and are frequently in short supply in aquatic ecosystems, } \\
\text { which limits plant and algae growth. ( Boyd and Boston Water } \\
\text { quality: An introduction, 2000) Consequently, the release of nutrients } \\
\text { into water bodies can result in the formation of large algae blooms or } \\
\text { eutrophication. (Boyd and Boston, Water quality: An introduction, } \\
2000 \text { ) Rapid algae growth and decay often release toxic chemicals and } \\
\text { deplete dissolved oxygen needed by fish. (Boyd and Boston, Water } \\
\text { quality: An introduction, } 2000 \text { ) In addition, some nitrogen compounds } \\
\text { can be toxic to humans and aquatic life. (Alberta, Water Quality } \\
\text { Testing,2012) }\end{array}$ \\
\hline
\end{tabular}

Volume 5 Issue 6, June 2016 www.ijsr.net

Licensed Under Creative Commons Attribution CC BY 


\section{International Journal of Science and Research (IJSR) \\ ISSN (Online): 2319-7064}

Index Copernicus Value (2013): 6.14 | Impact Factor (2015): 6.391

\begin{tabular}{|c|c|c|}
\hline $\begin{array}{l}\text { Organic } \\
\text { chemicals }\end{array}$ & $\begin{array}{l}\text { Includes benzene, diazinon, toluene, } \\
\text { vinyl chloride, and others }\end{array}$ & $\begin{array}{l}\text { Organic or carbon-based chemicals are usually associated with } \\
\text { industrial solvents, pesticides, coal, and oil. (Guidelines for Canadian } \\
\text { Drinking Water Quality - Summary Table, 2010) Many organic } \\
\text { chemicals are considered to be carcinogenic and toxic both to humans } \\
\text { and aquatic organisms. (Guidelines for Canadian Drinking Water } \\
\text { Quality - Summary Table, 2010, Benzene Guideline Technical } \\
\text { Document: Guidelines for Canadian Drinking water Quality, 2009) }\end{array}$ \\
\hline $\begin{array}{l}\text { Dissolved } \\
\text { oxygen }\end{array}$ & Oxygen present in water & $\begin{array}{l}\text { Dissolved oxygen is essential for the respiration of aquatic organisms } \\
\text { including fish. (Boyd and Boston, Water quality: An introduction, } \\
\text { 2000) Dissolved oxygen can be used up by algae and microbes when } \\
\text { nutrient levels are high. (Boyd and Boston, Water quality: An } \\
\text { introduction, 2000) }\end{array}$ \\
\hline $\mathrm{pH}$ & $\begin{array}{l}\text { Measure of water acidity. } \mathrm{pH} \text { is } \\
\text { measured on a scale from } 0-14 \text {, where } \\
\text { water with a } \mathrm{pH} \text { of } 7 \text { is neutral, a } \mathrm{pH} \\
\text { lower than } 7 \text { is acidic and higher than } 7 \\
\text { is basic }\end{array}$ & $\begin{array}{l}\text { Waters with a pH in the range of 6.5-9 are the most suitable for aquatic } \\
\text { life. (Boyd and Boston, Water quality: An introduction, 2000) If the } \\
\mathrm{pH} \text { is higher or lower it can result in gill tissue damage in fish. (Boyd } \\
\text { and Boston, Water quality: An introduction, 2000) A pH between } 6.5 \\
\text { and } 8.5 \text { is recommended for drinking water, largely to prevent water } \\
\text { pipe corrosion. (Guidelines for Canadian Drinking Water Quality - } \\
\text { Summary Table, 2010). The mobility of metals and minerals also } \\
\text { depends on pH; most metals are more likely to dissolve at lower pH } \\
\text { and therefore more likely to enter water bodies, contributing to the } \\
\text { environmental impact of acidic rock drainage. (Younger et.al,2002) }\end{array}$ \\
\hline Radionuclides & $\begin{array}{l}\text { Compounds that radioactively decay and } \\
\text { emit nuclear radiation, measured in } \\
\text { Becquerels }(\mathrm{Bq}) \text { per litre. Includes } \\
\text { radium-226 (Ra-226), cesium-137, } \\
\text { iodine-131, lead-210, strontium-90, and } \\
\text { others } \\
\end{array}$ & $\begin{array}{l}\text { Radiation emitted from radionuclides can damage DNA in people and } \\
\text { other organisms which can lead to organ failure or cancer. (Guidelines } \\
\text { for Canadian Drinking Water Quality: Guideline Technical Document } \\
\text { - Radiological Parameters, } 2010 \text { ) }\end{array}$ \\
\hline $\begin{array}{l}\text { Total } \\
\text { suspended } \\
\text { solids (TSS) }\end{array}$ & $\begin{array}{l}\text { The fraction of sediment small enough } \\
\text { to remain suspended in the water }\end{array}$ & $\begin{array}{l}\text { Suspended solids restrict light penetration through water, bury bottom- } \\
\text { dwellers, and clog fish gills, resulting in a negative effect on the health } \\
\text { of aquatic ecosystems. (Boyd and Boston, Water quality: An } \\
\text { introduction, 2000) TSS also introduces contaminates attached to the } \\
\text { sediment. (Metro Vancouver. Physical and chemical analysis of water } \\
\text { supply,2011) }\end{array}$ \\
\hline Turbidity & $\begin{array}{l}\text { A measure of the relative clarity or } \\
\text { cloudiness of water }\end{array}$ & $\begin{array}{l}\text { Turbidity is an indirect measurement of total suspended solids. (City } \\
\text { of Vancouver. Drinking Water Quality } 2011 \text { Annual Report, 2011) }\end{array}$ \\
\hline $\begin{array}{l}\text { Specific } \\
\text { conductivity }\end{array}$ & $\begin{array}{l}\text { The ability of water to conduct an } \\
\text { electrical current, measured in } \\
\text { microsiemens per centimeter }(\mu \mathrm{S} / \mathrm{cm})\end{array}$ & $\begin{array}{l}\text { Specific conductivity is related to the total ion concentration of water, } \\
\text { and is used to estimate the dissolved solid content including salts and } \\
\text { dissolved metals. (Guidelines for Interpreting Water Quality Data, } \\
\text { 1998) }\end{array}$ \\
\hline Toxicity & $\begin{array}{l}\text { Degree to which water is toxic to aquatic } \\
\text { life. Toxicity tests are usually conducted } \\
\text { on waste water being discharged into } \\
\text { river, streams, and lakes. }\end{array}$ & $\begin{array}{l}\text { Because different water quality parameters can combine to make water } \\
\text { more hazardous to aquatic life than the individual concentrations } \\
\text { would suggest, toxicity tests are commonly conducted using rainbow } \\
\text { trout or Daphnia magna (water fleas). (Biological Test Method Series, } \\
2012 \text { ) The fish or fleas are placed in different concentrations of waste } \\
\text { water for } 96 \text { hours, and a lethal concentration (LC) at which } 50 \% \text { of } \\
\text { the organisms die is recorded; water with a lower LC50 is considered } \\
\text { to be more toxic. (Acute Lethality Test Using Rainbow Trout, } \\
\text { Environmental Protection Series, 2007) }\end{array}$ \\
\hline
\end{tabular}

\section{References}

[1] Alberta, (2012)Alberta Ministry of Environment and Sustainable Resource Development. Surface Water Quality Program,

[2] AQUAMIN, 1996 ; Environment Canada. AQUAMIN Working Groups 7 and 8. Assessment of the Aquatic Effects of Mining in Canada:

[3] Boyd, C.E.,and Boston (2000) Water quality: An introduction, , MA: Kluwer Academic Publishers.

[4] British Columbia, British Columbia Ministry of Environment, Lands and Parks Guidelines for Interpreting Water Quality Data, 1998

[5] Canada, Environment Canada. Biological Test Method Series, 2012 [cited 2012 June 12];
[6] Canada, Environment Canada. Biological Test Method: Acute Lethality Test Using Rainbow Trout, Environmental Protection Series, 2007

[7] Canada, Health Canada. Cyanide, Environmental and Workplace Health, 2008 [cited 2012 June11

[8] Canada, Health Canada. Guidelines for Canadian Drinking Water Quality - Summary Table, 2010

[9] Canada, Health Canada. Guidelines for Canadian Drinking Water Quality: Guideline Technical Document - Radiological Parameters, 2010

[10] CBC News Online. Inside Walkerton, In Depth, 2004.

[11]City of Vancouver. Drinking Water Quality 2011 Annual Report, 2011

[12] Cuomo.F ,Della Luna.S, U. Monaco, U, and T. Melodia "Routing in ZigBee: Benefits from Exploiting the IEEE 802.15.4 Association Tree", Proc. of IEEE International Conference on Communications, Glasgow, Scotland, June 2007, pp. 3271-3276.

\section{Volume 5 Issue 6, June 2016 www.ijsr.net}




\section{International Journal of Science and Research (IJSR) \\ ISSN (Online): 2319-7064}

Index Copernicus Value (2013): 6.14 | Impact Factor (2015): 6.391

[13]E-Tech International. Evaluation of Predicted and Actual Water Quality Conditions at the Marlin Mine Guatemala, 2010 [cited 2012 June 19];

[14] Giannopoulos N, Giannopoulos.C, A. Kameas "Design Guidelines for Information Security,Beijing, China, June 2010, pp. 593-597.

[15] Giannopoulos.N, Giannopoulos.C, A. Kameas "Design Guidelines for Building a Wireless Sensor Network for Environmental Monitoring" Proc. of 2009 Panhellenic Conference on Informatics, Corfu Greek, September 2009, pp. 148-152.

[16] Jelicic. Vana, Razov Tomislav. Oletic, Kur. Marijan, and Bilas Vedran "MasliNET: A Wrielsess Sensor Network based Environmental Monitoring System" MIPRO, Proceedings of the 34th International Convention, Opatija, Croatia, May 2011, pp. 150-155

[17] Metro Vancouver. Physical and chemical analysis of water supply: Greater Vancouver Water District, 2011 [cited 2012 June 4];

[18] MIPRO (2011) A Wireless Sensor Network based Environmental Monitoring System", proceedings of the $34^{\text {th }}$ International convention, Opatija, Croatia, ,pp.150155.

[19] Mittal Runchi and Bhatia M.P.S "Wireless Sensor Networks for Monitoring the Environmental Activities" Computational Intelligence and Computing Research (ICCIC),IEEE International Conference,Coimbatore,India,December 2010,pp,1-5

[20] Mummey Daniel L.; Stahl, Peter D.; Buyer, Jeffrey S. (2002). "Soil microbiological properties 20 years after surface mine reclamation: spatial analysis of reclaimed and undisturbed sites". Soil biology and chemistry 34: 1717-1725. doi:10.1016/s0038-0717(02)00158-x.

[21] Niyogi, Dev K.; William M., Lewis Jr.; McKnight, Diane M. (2002). "Effects of Stress from Mine Drainage on Diversity, Biomass, and Function of Primary Producers in Mountain Streams". Ecosystems(5): 554567.

[22] Pyatt, F. B.; Gilmore, G.; Grattan, J. P.; Hunt, C. O.; McLaren, S. (2000). "An Imperial Legacy? An Exploration of the Environmental Impact of Ancient Metal Mining and Smelting in Southern Jordan".Journal of Archaeological Science 27: 771778.doi:10.1006/jasc.1999.0580.

[23] Renberg. I ,Ek, A. S.;. (2001). "Heavy metal pollution and lake acidity changes caused by one thousand years of copper mining at Falun, central Sweden".Journal of paleolimnology 26 (1): 89-107.

[24] Ryan, Paddy A. (1991). "Environmental effects of sediment on New Zealand streams: a review". New Zealand Journal of Marine and Freshwater Research25: 207-

[25] Steinhauser, Georg; Adlassnig, Wolfram; Lendl, Thomas; Peroutka, Marianne; Weidinger, Marieluise; Lichtscheidl, Irene K.; Bichler, Max (2009). "Metalloid Contaminated Microhabitats and their Biodiversity at a Former Antimony Mining Site in Schlaining, Austria". Open Environmental Sciences3: 26-41. doi:10.2174/1876325100903010026.

[26] Tarras-Wahlberga, N.H.; Flachier, A.; Lanec, S.N.; Sangforsd, O. (2001). "Environmental impacts and metal exposure of aquatic ecosystems in rivers contaminated by small scale gold mining: the Puyango River basin, southern Ecuador". The Science of the Total Environment 278: 239-261. doi:10.1016/s00489697(01)00655-6.

[27] Yang. Y and X. Li, "Design and implementation of lowpower wireless Sensor networks for environmental monitoring", Proc. of IEEE International Conference on Wireless Communications, Networking and Information Security,Beijing, China, June 2010, pp. 593-597.

[28] Younger, P.L., S.A. Banwart, and R.S. Hedin, Mine Water: Hydrology, Pollution, Remediation, 2002, Dordrecht, The Netherlands: Kluwer Academic Publishers.

[29]ZigBee specifications, ZigBee Alliance Std, 2005.

Volume 5 Issue 6, June 2016 www.ijsr.net 